\title{
Response of Mangrove Shorelines to Sea-level Change
}

\author{
Colin D. WOODROFFE School of Geosciences, University of Wollongong, Wollongong, NSW 2522, Australia
}

\begin{abstract}
The response of mangrove shorelines to sea-level change is a function theiroverall sediment budget. Whereas mangroves have often been viewed as a source oforganic productivity which is supplied to adjacent estuarine waters, they are generallyconsidered a sink for sediments. Though often displaying a shore-parallel zonation ofmangrove species, this need not indicate succession, or that the shoreline is prograding.Despite pronounced zonation, such as in southwestern Florida where mangroves occuradjacent to freshwater wetlands of the Everglades, interpretations based upon stratigraphyhave ranged from a view of mangroves as builders of land, to one of retreat as a result ofsea-level rise over the past few thousand years. Fossil mangrove material may be used todetermine the pattern cf fluctuations of sea level over the late Quaternary, and may alsoindicate the nature of rsponse of mangrove shorelines to past sea-level changes.Mangrove sediments provide a relatively good record of sea-level rise, particularly wherethere has been a rapid supply of inorganic sediment to the coast, but are poorer indicatorsof sealevel fall or periods of stable sea level. The function of mangrove ecosystems differsin different environmental settings, and a framework is proposed within which to view therole of mangroves. Sedimentation beneath mangroves modifies the way in which theshoreline responds to changes in sea level, and the timescale over which sedimentation rateis considered is likely to influence the way in which mangroves appear to have responded.Future changes are to be expected on mangrove shorelines, but differentiating betweennatural changes, human-induced changes, or responses to global environmental change willbe difficult, and may differ between locations.
\end{abstract}

Key Words: mangroves / sedimentation / sea-level rise / slobal environmental change

Mangroves are currently recognised as important tropical coastal wetlands, reaching their most diverse in the Old World, in the Indo-West Pacific region, and with a second centre of diversity in the New World, centred on the West Indies (Chapman, 1976). Their value lies not only in terms of goods, such as timber and charcoal derived directly from the mangroves themselves, and fish and other aquatic resources indirectly supported by inputs from the mangroves, but also from a series of lesstangible services which mangroves provide, such as shoreline protection and sediment and nutrient trapping (Hutchings \& Saenger, 1987). Whereas, in a biological context, a view has developed that mangroves are a source of organic productivity, which through a process of outwelling, supports associated nearshore or estuarine ecosystems, in a geological context, mangrove shorelines are regarded as a sediment sink. In practice, the paradox between a biological source and a geological sink is easier to resolve when it is appreciated that tidal flushing of mangrove forests is a complex phenomenon, with marked spatial and temporal variability. The flooding and draining of mangrove forests occurs in most instances via tidal creeks; large volumes of water are exchanged in both directions, and the net flux represents a small proportion of the total budget, whether it be of nutrients, detritus or sediment. 


\section{A) after Davis}

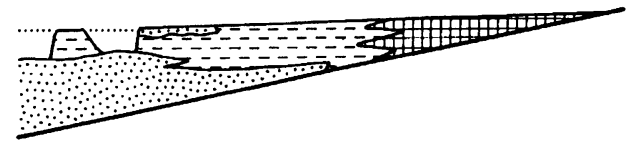

B) after Egler

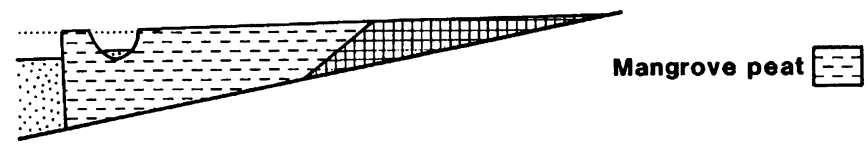

C) after Scholl

Fresh-water peat

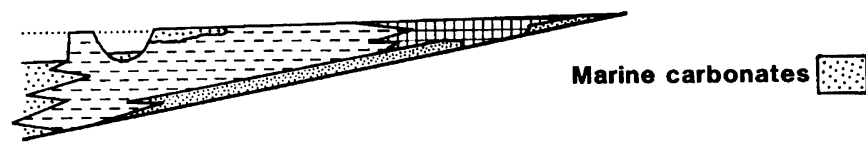

D) after Spackman et al. Fresh-water

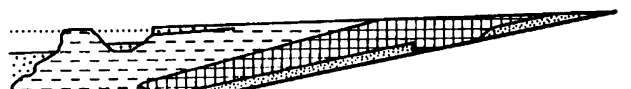

Quartz sand $\because$

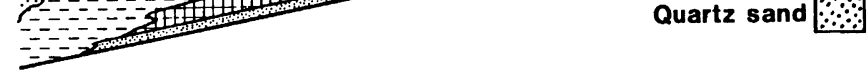

E) after Parkinson

Oyster reef

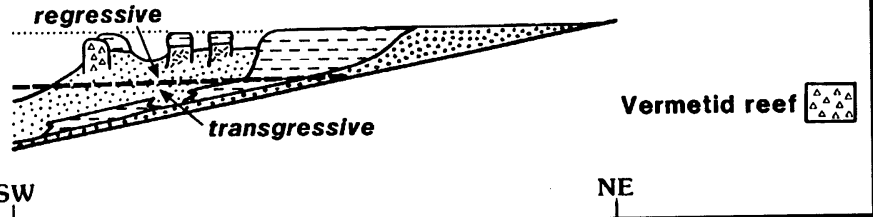

Fig. 1 Schematic representation of the Holocene stratigraphy of southwestern Florida and its significance for the interpretation of the geomorphological development of mangrove shorelines by a series of researchers. (from Woodroffe, 1990). See text for details.

It has been traditional to view mangrove species patterning as representing a zonation of species from landward to seaward. When viewed in conjunction with the ability of mangrove propagules to establish on muddy substrates seaward of the existing mangrove fringe, this has lead to a popular conception that mangroves are capable of reclaiming land from the sea (Carlton, 1974; Davis, 1938). The view of mangroves as successional stages in the replacement of an intertidal vegetation by dryland vegetation, championed by Chapman, needs to be reassessed. The realisation that mangroves occur in areas which have been, and may continue to be, influenced by sea-level change, adds a further dimension to the evolution of mangrove shorelines. 


\section{Stratigraphy and Mangroves Development in Southwestern Florida}

Successive interpretations of the stratigraphy of sediments in southwestern Florida, provide an interesting perspective on the revision of these earlier interpretations, and our growth in understanding of the long-term dynamics of mangroves. In southwestern Florida the extensive Everglades comprise a freshwater wetland system dominated by grasses and sedges. These grade into a relatively simple, but extensive mangrove complex, which flanks Florida Bay. Fig. 1 summarises, in highly schematic form, the interpretations advanced to explain the late Holocene development of the area, as further insight was gained into the stratigraphy and age of the sediments underlying the plains. Davis, describing situations in which mangroves are actively colonising calcareous mudbanks in the Bay, interpreted carbonate sediments which he observed beneath the peat underlying mangroves as marine and indicated that the mangrove forests had formed by gradual extension over the calcareous sediments of the Bay. This progradational role which Davis invoked (Davis, 1940) was enthusiatically adopted by Chapman to account for vegetational processes in Jamaica (Chapman, 1944). Egler, on the other hand, realised that mangrove peats of several metres thickness, and hence exceeding the tidal range, must have been deposited as the sea had risen (Egler, 1952). Under such conditions he inferred that mangroves might be advancing landwards into the Everglades vegetation. The detailed stratigraphic work of Scholl, combined with radiocarbon dating of mangrove peats and the realisation that the calcareous mud beneath the mangrove peat was actually deposited under freshwater conditions, lead to interpretation of the freshwater-intertidal-marine sequence as transgressive, recording gradual sea-level rise at a decelerating rate up to present (Scholl, 1964; Scholl \& Stuiver, 1967). More detailed studies on the petrology of the peats, including pollen content, by Spackman and his colleagues, lead to further refinement of this model (Smith, 1968; Spackman et al., 1966). It was shown that in some cases the lower peat had been deposited under freshwater conditions and was overlain by mangrove peat, indicating that the trangression actually lay within the peat sequence rather than at its base. Subsequently more detailed analysis of other parts of the southwestern Florida coastline has revealed more complex geomorphological records, and Parkinson has identified a lower transgressive sequence of sediments with an upper regressive sequence (Parkinson, 1989). In other words, the shoreline intially moved landwards as the sea rose at a rate greater than $3 \mathrm{~mm} \mathrm{yr}^{-1}$, but that it has susequently built seawards, through development of oyster and vermetid reefs, as well as mangrove progradation, in the late Holocene since the rate of sea-level rise has slowed below $3 \mathrm{~mm}$ $\mathrm{yr}^{-1}$.

\section{Mangrove Zonation and Dynamics}

It is no longer appropriate to assume that zonation of mangroves necessarily reflects gradual progradation of the mangrove shoreline. Mangrove patterning may, instead, be opportunistic, with mangroves growing in conditions that are favourable for the growth of individual species; there may be no obligate replacement of a mangrove zone by a more landward zone over time (Thom, 1967). Indeed it is interesting to note that in the Port Royal, where Chapman advanced the concept of mangroves as progradational, that long-term studies of the extent of mangroves, do not detect any substantial build-out of the shore (Alleng, 1998). Mangroves may show a zonation which exists in a 


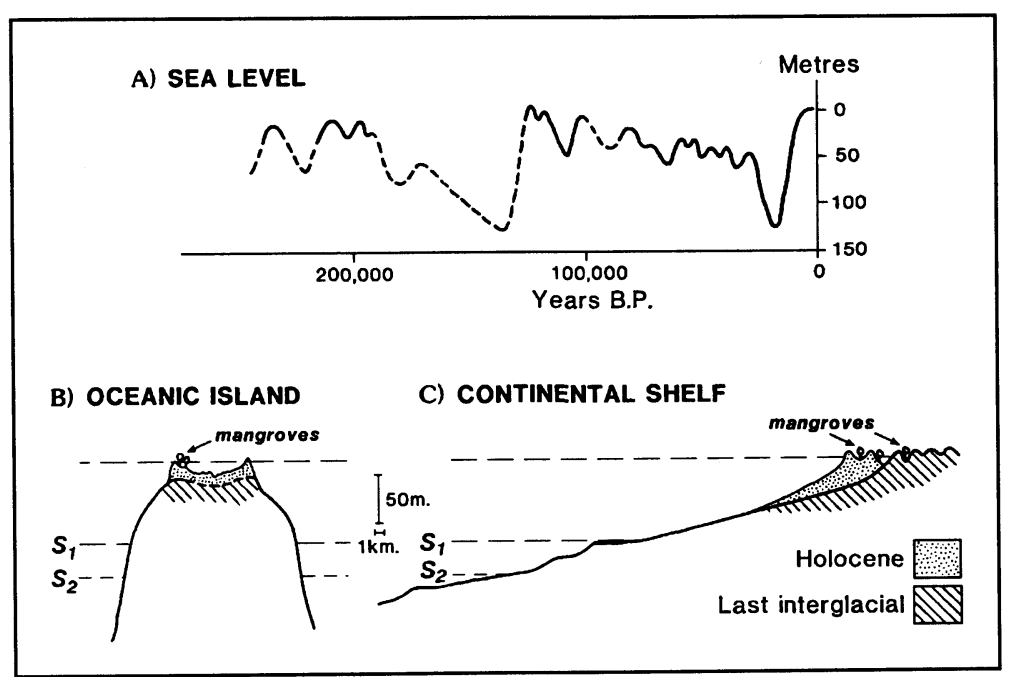

Fig. 2 a) Broad pattern of eustatic sea-level change over the last 240,000 years. (after Chappell \& Shackleton, 1986) b) Morphology of shoreline on typical oceanic island illustrating how environment is favourable for mangrove establishment during the late Holocene, but may not have been at lower sea level (such as S1 or S2). c) Continental shelf showing how mangrove may have persisted when the sea was lower. (after Woodroffe, 1990).

steady state; indeed Semeniuk has described zonation on an eroding shoreline in northwestern Australia, where sheet erosion appears to strip the substrate from beneath the mangroves (Semeniuk, 1980). Such landward retreat of a zoned mangrove shoreline might also be expected to have occurred at times in the Holocene when sea-level rise was rapid and the shoreline was migrating landwards.

We now know that there have been a series of fluctuations of sea level during the Quaternary as the volume of water held in the ice sheets or in the oceans has oscillated with climate changes (Chappell \& Shackleton, 1986). On the one hand, fossil mangrove deposits are useful because they enable us to constrain the former positions of the sea; thus radiocarbon dates on mangrove peat were used by Scholl to reconstruct the pattern of sea-level rise in Florida (Scholl et al., 1969). On the other hand, studying how mangroves themselves reacted to these changes in sea-level may enable us to better understand how mangroves might respond to any future changes in sea level (Woodroffe, 1990).

Sea level is now considered to have undergone a series of oscillations through the Quaternary, with a maximum amplitude of around of 100-120m, over a timescale of around 100,000 years, driven primarily by orbital changes (Chappell \& Shackleton, 1986). The broad pattern is glacio-eustatic, global in nature, and is reflected in oxygen isotope records from deep-sea cores. Over the last few thousand years, however, there is considered to have been relatively little net ice melt, and the mid and late Holocene have been dominated less by the overall global pattern of eustatic sea-level change, than by regional anomalies reflecting the isostatic response of the ocean basins and continental margins to the redistribution of water masses (Fig. 2). This has resulted in a substantial difference between the pattern of Holocene sea-level change in the New World mangrove region and the Old 
World mangrove region. In the New World, typified by the record from Florida, there has been a gradually decelerating rise of sea level up to the present time. By contrast, in the Australian region, it is apparent that sea level reached a level close to its present around 6000 years ago, and that it has been close to, probably slightly above, or fluctuating around present since (Clark et al., 1978). This contrast between the pattern of sea-level rise in the New World and the Old World enables us to examine how effectively mangrove deposits may enable the reconstruction of sea level under several different patterns of sea-level change.

Information on sea level can be derived from various different types of fossil mangrove material. Mangrove pollen provides a broad perspective; pollen is easily carried beyond its source of production. Some pollen is anemophilous (wind-blown), and may be carried considerable distances; mangrove pollen is also subject to movement in the water column and thus can be well-represented in nearshore sediments (Van Andel, 1967). Mangrove pollen thus provides a broad indicator that the coastline has been near, but individual pollen grains may travel substantial distances from the coast. On the other hand, beneath mangrove forests mangrove pollen far exceeds any other pollen, and detailed pollen spectra may enable the reconstruction of mangrove species patterning (Grindrod \& Rhodes, 1985; Grindrod, 1988).

Mangrove wood fragments, often distinctive (such as the reddish, fibrous material characterising Rhizophora) from the wood of terrestrial vegetation, also serves to indicate intertidal areas. However, the evidence is rarely definitive, as wood from mangroves may be washed into the nearshore, or penetrate as roots into the sediments below the mangroves. Mangrove stumps are perhaps the most indicative of fossil mangrove material. Where former stumps are found in their position of growth, they indicate that this area was formerly intertidal, thus stumps are found along many of the tidal rivers in northern Australia, although in this case as the tidal range is large, there remains a fair degree of imprecision as to exactly where former mean sea level was (Woodroffe et al., 1985).

Mangrove remains have been important as indicators of the pattern of Holocene sea-level change in the tropics. The fact that the sea-level curve (confirmed using independent evidence, such as reef deposits) has differed between the New World and the Old World, and at least in the latter has consisted of periods of relatively stable, and gradually falling sea level, as well as sea-level rise, enables a comparison of the effectiveness of mangrove deposits as sea-level indicators under different scenarios. A fuller review of the evidence is given by Woodroffe (Woodroffe, 1990.) It is clear that mangrove sedimentation cannot keep up with the fastest rates of sea-level rise experienced during the postglacial transgression. If it could then there would be up to 100-120 m thickness of mangrove sediments recording the position of mangroves at the peak of the glaciation. Instead, though mangrove peats are found at various places across the broad continental shelves, as for instance in the Sunda and Sahul shelves, present coastal sedimentary wedges are rarely more than 15-20 m thick, recording continuous mangrove sedimentation only during the mid to late Holocene, as sea level rise began to slow.

Mangrove sediments provide a relatively good record of sea-level rise, particularly where the sediments are of high bulk density (thus low organic content), low compressibility, and rapid sea-level rise. Such is the case along the north Australian coast, and mangrove facies record the pattern of sea level from around 8000 years BP to around 6500 years BP from both northeastern Queensland (Grindrod \& Rhodes, 1984) and the Northern Territory (Woodroffe et al., 1987), a pattern broadly 
consistent with that emerging from the dating of coral records from Papua New Guinea and the Abrolhos Islands.

Mangrove deposits have been used to decipher the pattern of sea-level rise in the New World. Here however, the sediments are highly organic mangrove peats. These are subject to compaction, and also to root penetration of younger material, which combine to mean that radiocarbon dates may be significantly younger than sea level indicated by other means (such as the Acropora palmata curve of Lighty et al., 1982). As sea level decelerated, the accuracy with which sea-level position can be inferred from mangrove peat dates declines.

Mangrove wood appears to be a poorer indicator of the pattern of sea level during a period when sea level has been stable. Thus in northern Australia, though sediments are less compactable than the peats of the New World, due to their higher inorganic content, those dates from cores underlain by great thicknesses of unconsolidated sediment are less reliable than basal dates, taken from mangrove facies overlying a lithified bedrock, and thus not likely to be subject to compaction. The exact pattern of sea-level change in northern Australia remains unclear in the Northern Teritory, because of the large tidal range. Thus even where in situ stumps have been dated, problems of potential postdepositional contamination are hard to avoid; it seems likely that deposits may have been subject to further addition of roots since initial deposition, and sea level cannot be reconstructed with accuracy. Corals, particularly large flat-topped corals, termed microatolls, are a much more precise indicator of where sea level stood, especially in northeastern Australia. Where, as in Princess Charlotte Bay, detailed reconstructions have been possible from both extensive radiocarbon-dating of mangrove facies beneath a progradational chenier plain, and from sequences of microatolls offshore, there is a disparity between them, further raising the question as to how reliable mangrove deposits are in these circumstances (Chappell \& Grindrod, 1984).

Mangroves are still less reliable as indicators of emergence. Various accounts of the Holocene sealevel history from the Malay Pennisula indicate that sea level was above present around 6000 years ago, and that it has fallen since that time (Tjia, 1996). Such a pattern was reported by Geyh et al. (1979), who described mangrove stumps in situ from the Malacca coast. However, the sediments resulting from that emergence have been subject to a number of problems. First the fall in the water table means that the organic material is especially subject to oxidation. Furthermore, the deposits are liable to penetration of roots from vegetation which replaced mangroves, such as the freshwater peat swamp forests that formed over much of the Malaysin and Indonesian coasts.

Thus mangrove deposits can be particularly useful in recording past sea level where sea level has risen rapidly and inorganic sediments have been supplied rapidly. Rarely in these cases can stumps be discerned, but the sea evidently rose rapidly, and whatever organic material was deposited was rapidly buried. When the rate of sea-level rise slowed, an organic-rich facies, called the big swamp in northern Australia, was deposited, but, despite the abundance of stumps in riverbank exposures, it becomes harder to detect the exact trend of sea level, because where tidal range is large stumps could be the result of sea level within a broad vertical range. Indeed in northeastern Australia the sedimentary record has been interpreted to contain fluctuations within it (Gagan et al., 1994). Mangrove pollen has been used to detect the species complement of the mangrove forests, and a transition can be recognised from a wide region in the Top End (Clark \& Guppy, 1988) and in northeastern Australia (Crowley, 1996); however, these deposits provide few details of the sea-level 


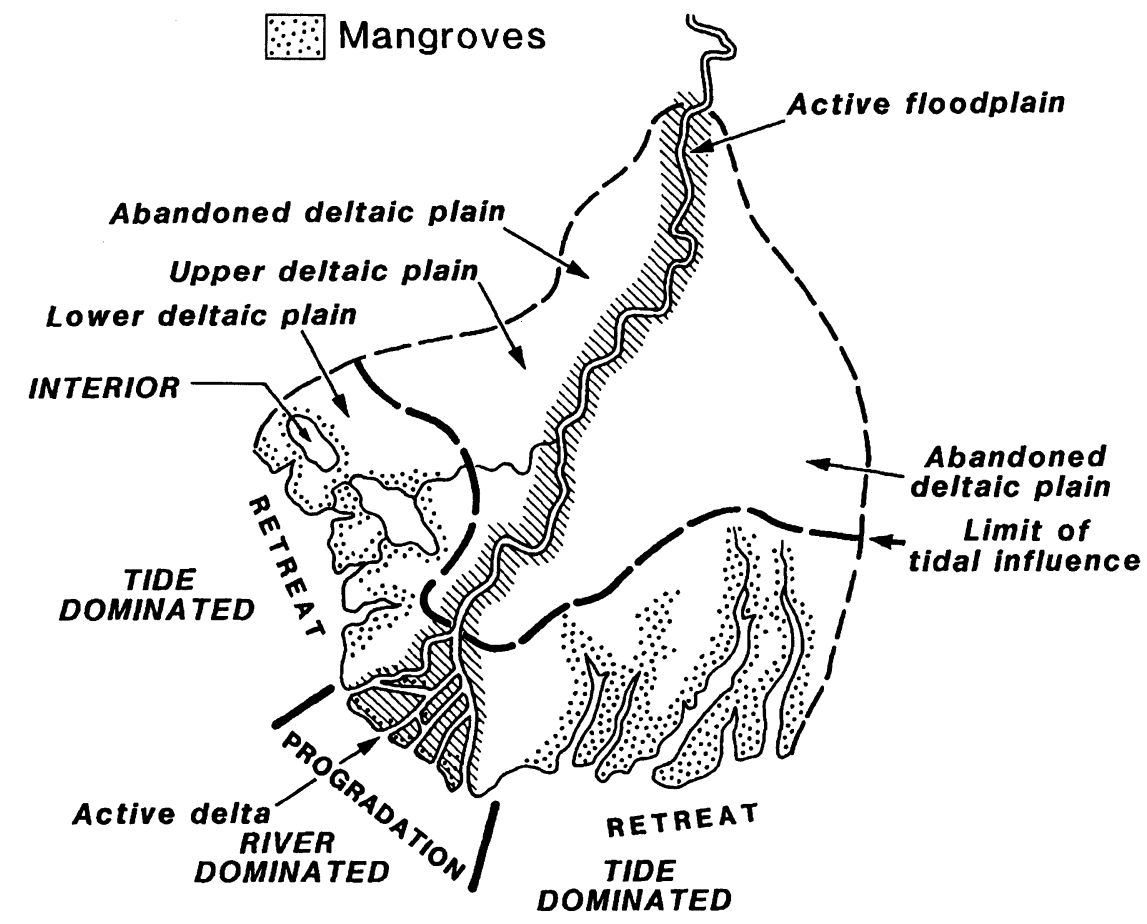

Fig. 3 An example of a river-dominated mangrove setting. A typical schematic southeast Asian delta, illustrating the broad geomorphologically-defined habitats, within some of which mangrove may be variously river-dominated, tide-dominated or interior. (from Woodroffe, 1995). See text for details.

response.

In the New World, the mangrove peat deposits, charcteristic of the largely-calcareous setting within which mangroves are most extensive, or have been most studied, provide only a broad picture of how sea level has risen. As the rate of sea-level rise has slowed, the precision with which mangrove deposits enable sea-level reconstruction decreases (Woodroffe, 1981).

It is thus becoming clear that mangroves have not behaved the same in all places. The pattern of sea-level change has been one of the major determinants; whereas the degree to which mangrove organic matter contributes to the sediments is a further determining factor. In order to understand these differing geomorphological roles, it is useful to distinguish various mangrove settings. This concept was developed by Thom (Thom, 1982) It has been further developed by Woodroffe who distinguished, river-dominated settings (such as river deltas), tide-dominated settings, and carbonate settings (Woodroffe, 1990; Woodroffe, 1992).

River-dominated settings are those within which there is a substantial input of river flow. The deltas of large tropical rivers tend to be areas which have extensive mangrove forest development. Tidally dominated mangroves occur where there is a large tidal range, or where other factors such as river input (or wave energy) are low. The macrotidal estuaries of the north Australian coastline are tidally-dominated, but so also are other mangroves fringing coastlines where there is substantial 


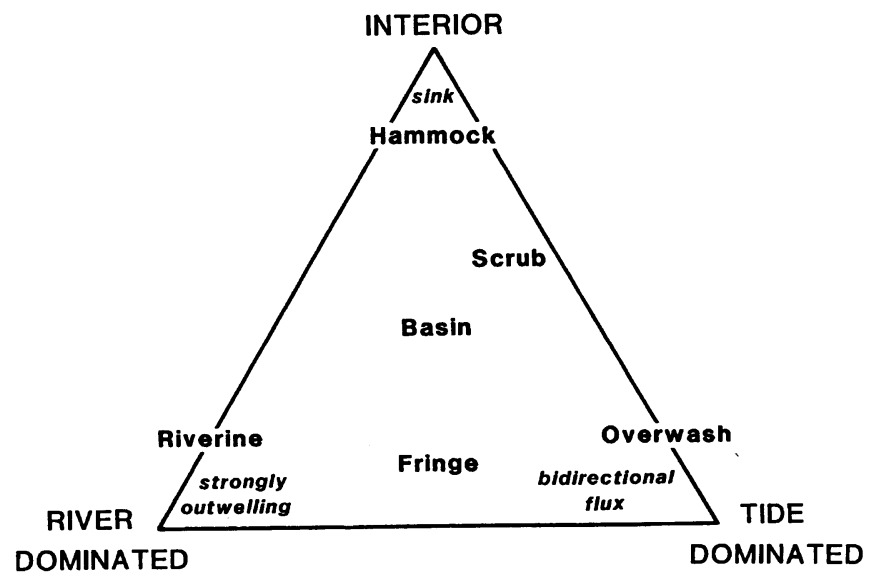

Fig. 4 A ternary diagram representing a continuum of processes affecting mangroves or settings within which mangroves are found. (after Woodroffe, 1992)

clastic sediment and it is reworked primarily by tidal action, even though the range may not be large. Carbonate settings are those in which there is not a large clastic sediment supply, but in which sediments are calcareous. These include reef settings, where mangroves may develop in the lee of reefs, or on sheltered reef flats, carbonate banks, such as the Great Bahama Bank or Florida Bay, and the mangrove forests developed behind beach ridges on limestone (often fossil reef) islands. In these cases there is generally not a large supply of allochthonous sediment, and the underlying sediments are either calcareous bioclastic sands, or muds, or mangrove peats which have been derived almost entirely from the growth of mangrove roots and detritus.

In addition to these broad settings it is clear that mangroves function differently both between these different settings, and also in different habitats within any one setting. Thus in the case of riverdominated settings, the actual distribution of mangroves in relation to a typical schematic Southeast Asian delta is shown in Fig. 3. Mangroves are generally not well-developed at the mouth of the delta in the active delta plain, but tend to be much better developed in the abandoned delta plain. The reasons for this are several. First the river discharge is largely freshwater providing ecological conditions in which other vegetation may outcompete mangroves, and flow is from upstream making the disperal of mangrove propagules to suitable sites more difficult, large sediment loads are moved down the river, the delta environments may be characterised by large islands which prograde rapidly seaward as further sediment is brought down the river. On the other hand the shoreline of the abandoned delta plain is generally irregular and tidally-dominated. It is often subsiding as the whole delta responds to the load of sediment added to the shelf, but as no further sediment addition occurs because the major flow is now diverted from its former courses, the area may be gradually becoming more tidally-dominated. These abandoned distributaries provide ideal habitat for mangrove establishment, they are flooded largely by tidal flows, and shoreline retreat is typical.

Thus various habitats exist within the mangrove forests of each setting. The function of the mangrove forests differs between these habitats, and with it the geomorphological processes in 
Table 1. Goods and services provided by mangrove forests, and a ranking of the relative significance of riverine, fringe and basin functional types in each case (modified from Ewel et al., 1998).

\begin{tabular}{llll}
\hline Trap sediments & Riverine & $>$ Basin & $>$ Fringe \\
Detritus supply to nearshiore & Riverine & > Fringe & $>$ Basin \\
Provision of nutrient sink & Basin & > Riverine & > Fringe \\
Support nearshore food web & Riverine & > Fringe & $>$ Basin \\
Aesthetically pleasing & Riverine & > Fringe & > Basin \\
Protection of shoreline & Fringe & > Riverine & $>$ Basin \\
Provision of plant products & Basin & > Riverine & > Fringe \\
\hline
\end{tabular}

operation. Lugo and Snedaker (1974) provided a useful functional classification of mangroves in their study of New World mangrove forests. They adopted the terms riverine, fringe, and basin mangroves, with further classes such as scrub, overwash and hammock mangroves.

The hydrological processes which operate in these different functional types of mangrove mean that they function differently not only in an ecological sense, but in a geomorphological sense. Thus in cases where there is a substantial river flow, sediments may be brought in from the river, and organic production, enhanced by the freshwater, may be exported with the flow, supporting the concept of outwelling. By contrast, those mangroves which are fringing small islands (for instance the overwash mangrove which consists of fringe on all sides) is flooded by the tides which pass through or into and out of such a small mangrove island. In this case ecological functioning and geomorphological operation is dominated by the bidirectional flux. Other areas of mangrove are relatively remote from direct flushing, and have been given the term basin mangrove. Scrub mangrove may represent a further example of such basin mangroves, in which the mangroves are dwarfed.

Fig.4 represents an attempt to integrate the concept of functional mangrove types with the broad geomorphological or hydrological processes which constrain the way in which the swamps function. It is important to realise that while there may be clear end members, often the degree to which river flow, or tidal flushing influence a mangrove swamp can vary spatially and temporally. Ewel et al (1998) have built upon this broad ternary diagram to emphasise further the variation in function (Ewel et al , 1998). Table 1 modifies their assessment of the relative significance of each of the broad types, riverine, fringe and basin in relation to the major goods and services provided by mangroves.

The positioning of particular mangrove stands in the ternary diagram is also an indication of sedimentary processes and their relative significance in the various mangrove types. In particular it is a reflection of the likely source and make-up of the sediment. Thus riverine mangroves are recipients of river-bourne sediment. These nutrient-rich sediments, together with the freshwater which enhances mangrove growth, leads to productive mangroves, from which there may be substantial outwelling of organic detritus. By contrast interior basin mangroves are more likely to be sinks for mangrove organic matter, and may also be sinks for nutrients and sediment. Fringe mangroves are subject to regular tidal flooding; they tend to be of higher productivity than basin mangroves, but material is readily exchanged and much of the production is removed from the forests.

While the functional classification proposed by Lugo and Snedaker (1974) has been widely adopted in the New World mangroves, it has met with less acceptance in the more complex mangroves of the New World. Nevertheless, as a framework within which to view the functioning of different elements of the mangrove ecosystem it offers a useful template. This is illustrated with an 

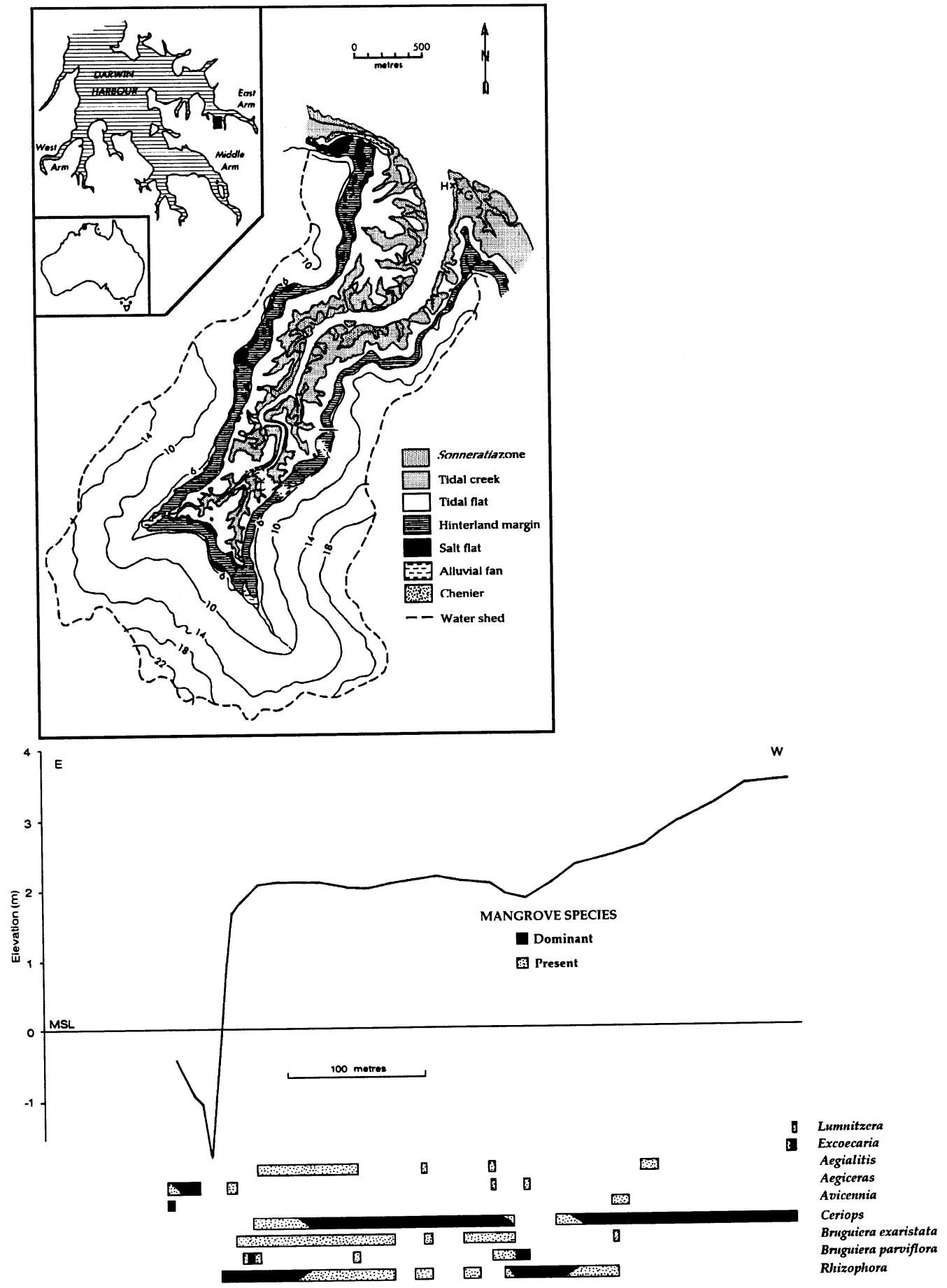

Fig. 5 The distribution of mangrove habitats in a typical creek within Darwin Harbour, showing Sonneratia zone, tidal creek, tidal flat and hinterland margin. Typical transect showing height and gradient of ground surface, and distribution of mangrove species. 


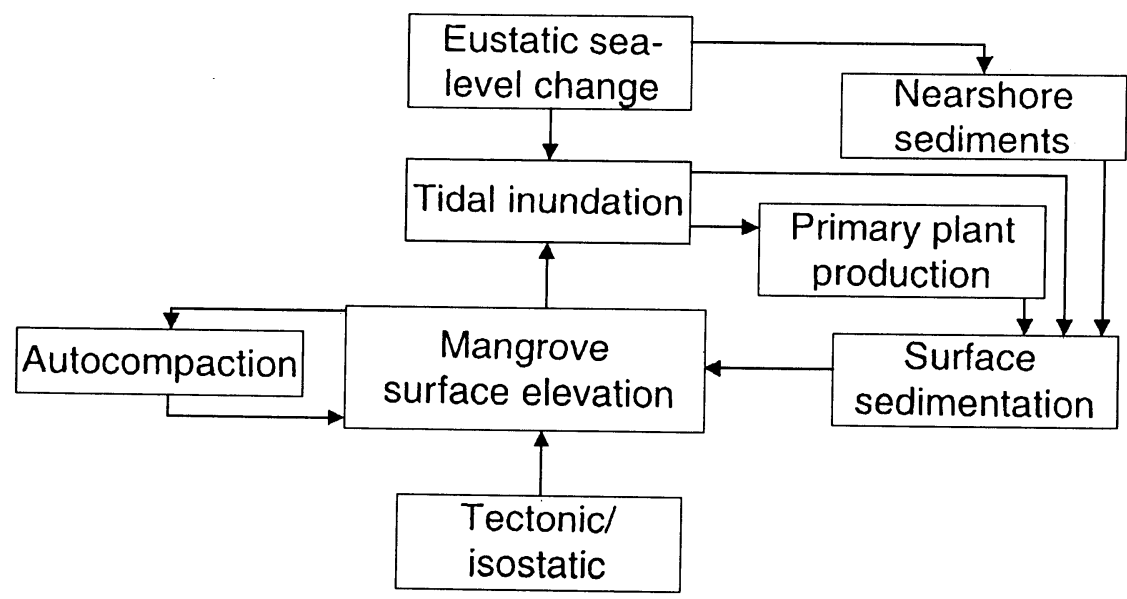

Fig. 6 A conceptual diagram showing the interaction of factors influencing sedimentation in mangroves. (modified from salt marsh studies by French, 1993)

example from northern Australia, from the mangrove forests flanking Darwin Harbour.

The mangroves flanking Darwin Harbour, cover more than 25,000 ha, and follow the broad pattern of species zonation proposed for the Indo-West Pacific by Macnae (Macnae, 1968). A typical transect is shown in Fig. 5. The transect is from a tidal creek to the landward (hinterland) margin where open Eucalypt forest occurs. A broad pattern of geomorphologically-defined mangrove communities has been described by Semeniuk (Semeniuk, 1985), who has recognised a tidal creek habitat, a tidal flat habitat, and a hinterland margin habitat (Semeniuk, 1985). Woodroffe et al. examined litterfall beneath the mangroves along a transect through these habitats and demonstrated that there were significant differences in the productivity of mangroves in these different units (Woodroffe et al., 1988). The pattern indicated significant trends across these units, as well as contrasts between them, somewhat in contrast to the use of the functional fringe, riverine, and basin categories in the simpler mangrove forests of the New World. Nevertheless, it is useful to recognise and apply the principles behind the differentiation of these functional types of mangrove. In the example creek chosen, there is only a very minimal catchment area for the creeks draining into the mangrove forests; these result in recognisable alluvial fans with distinctive mangrove associations (as described by Semeniuk for situations with more substantial inflow). However, there is negligible riverine influence in the case of this creek, in probable contrast to the mangroves fringing the larger rivers which seasonally drain into Darwin Harbour. On the other hand, direct influx of freshwater into the landward margin of the mangroves (the hinterland margin) is of significance (cf Semeniuk, 1983), at least in the wet season, and leads to a significant increase of stature and productivity of Ceriops to the rear of the mangrove, and to addition of colluvium to the substrate. A pronounced bare salt flat, associated with elevated salinities in the dry season, marks the transition between hinterland influence and the relatively flatter areas of tidal flat mangrove.

The tidal creek is the main route for flushing of mangroves and there is a direct influence associated with the proximity of the creek, such that the main division of the forests is into tidal creek 
and tidal flat mangroves. In many ways these resemble the fringe and basin types of mangroves. The tidal creek (fringe) contains the most productive stands of Rhizophora, whereas the tidal flat is dominated by low stature Ceriops and Bruguiera exaristata.

Sedimentary processes may also vary between mangrove forests of different functions, because the hydrological parameters which are significant in influencing the functioning of mangroves are also those which determine the supply and provenance of sediment. Indeed, as organic productivty is itself a major element of substrate development of many mangrove forests, it can account for much of the accretion of the substrate in some instances.

Fig. 6 shows a schematic illustration of the pattern of sedimentation beneath mangroves (modified from a conceptual model proposed for salt marsh accretion by French, 1993). The elevation of the mangrove substrate is a function of the rate at which accretion occurs, and that in turn is influneced by the frequency of tidal inundation, the supply of sediments from nearshore and the incorporation of plant productivity. The latter has received very little study; little is known about the extent to which below ground biomass is incorporated into the substrate, though it is clearly very variable, ranging from more than $80 \%$ in the mangrove peats of the New World, to less than $10 \%$ in some of the muddy mangrove deposits where there is abundant clastic sediment supply. In addition, the role of autocompaction is poorly understood, but again is likely to be an important factor where sediments are highly organic. External factors such as the tectonic or isostatic stability of the site, or sea-level change need also to be factored in.

Sedimentation rates beneath mangroves are difficult to measure, and yet the determination of the rate at which the substrate can accrete is one of the most important parameters in deciding whether a mangrove forests can keep pace with projected sea-level rise. Few attempts have been made to directly measure sedimentation rates, and those which have have yielded divergent estimates. Maximum rates of up to $1 \mathrm{~mm} \mathrm{yr}^{-1}$ using brick dust marker layers (New Zealand, Chapman \& Ronaldson, 1958), up to $4.6 \mathrm{~mm} \mathrm{yr}^{-1}$ in northern Australia and $8 \mathrm{~mm} \mathrm{yr}^{-1}$ in southern Australia using stakes (Bird, 1971; Spenceley, 1977, 1982), $3 \mathrm{~mm} \mathrm{yr}^{-1}$ in Mexico using $\mathrm{Pb}$ and Cs dating (Lynch et al., 1989), and up to $6 \mathrm{~mm} \mathrm{yr}^{-1}$ during the early Holocene in northern Australia from radiocarbon dating (Woodroffe et al., 1986), have been reported. The methods are highly different, and the results are not directly comparable. Still higher rates have been indicated by recent studies in eastern Malaysia (see Schahabudin, this volume), using buried plates.

Several studies have indicated that if mangroves only accrete sediment at the lowest rates cited, that they may collapse during imminent sea-level rise (Ellison \& Stoddart, 1991). However, there are several issues which require more concentrated research before such imminent loss of mangroves can be attributed to sea-level rise alone.

First the inadequacy of the estimates of sedimentation rates beneath mangroves needs to be recognised. Those which are based upon measurment against marker layers or stakes between years have only been in place for a short period of time. On the other hand the stratigraphically-determined rates of accretion are also a poor indicator of the potential rate of sedimentation. On the one hand, these average out variability within the mangroves, which, as discussed below, is likely to be considerable. Secondly there is a tendency for mangroves to appear to have accreted at the same rate as sea-level rise, because the rate of sea-level rise provides a direct constraint on the accommodation space, and hence the ability for accretion to occur. Thus, as shown above, there is a pattern by which 
from 8000-6000 years BP sedimentation appears to have matched the rise of sea level in northern Australia.

A further important element is the poor record of the contribution of organic production itself to the pattern of sedimentation beneath mangroves. Where sediment from outside is scarce, mangroves may fill in their substrate with root material. Again, the rate at which they do this is unlikely to exceed the rate of sea-levle rise, or unlikely to appear to do so, where basal sediment is dated to get an idea of the long term sedimentation rate. These sedimentation rates are likely to represent minimum values.

Perhaps more significantly there is liely to be considerable spatial variability in the sedimentation rate at differnet locations within the mangrove forest. Indeed, such variability is implicit in the conceptual model in Fig. 6, where sedimentation is seen as dependent upon the degree of tidal inundation. If this is the case then accretion would decrease as the substrate became further elevated through time. Further variability is likely in terms of the contribution of organic production; productivity has been shown to vary according to functional types of mangrove, and the incorporation of organic production nito the substrate seems likely to also vary spatially in a similar manner.

The argument for spatial variability in sedimentation rate will be advanced with reference to the typical transect through the mangroves in Darwin Harbour, shown in Fig. 5. Variation in sedimentation rate can be inferred from the fact that the profile is not uniform across the intertidal zone. The sediment wedge form, seen along tbis profile, as also elsewhere (Bird, 1986), implies that sedimentation rate is not uniform. Throughout Darwin Harbour there are steep gradients beneath the Rhizophora zone, implying that sedimentation has been faster than in adjacent areas in this zone.

The source of sediment is also variable across the transect. Perhaps the clearest source of sediment input is the colluvial input of material to the hinterland margin, demonstrated by the lag of sand and fine gravel across the landwardmost part of the transect, and the steeper gradient of the profile beneath this landward Ceriops. The Ceriops itself shows a gradient in height from adjacent to the hinterland vegetation to its most stunted beside the bare salt flats areas, where it is unable to grow. One can infer that tidal sediment is preferentially supplied to the tidal creek zone, and that the tidal flat zone, which is almost horizontal, receives less sediment than either tidal creek or hinterland margin. Whether the sediment below the Rhizophora zone, which would appear to be the most rapidly accumulating, receives a significant input from the highly organic input from Rhizophora roots, has not to the best of my knowledge been specifically tested.

Thus the conclusion of this paper is that there remains much that is unknown about the role of sedimentation under mangrove forests. Undoubtedly it is not the same for all mangrove forests, and an appreciation of the setting, and then the individual functional habitats within any one setting, will be important in furthering our understanding of how mangroves develop.

Studies of the stratigraphy of mangrove shorelines enable us to interpret how mangroves have developed in previous situations, and may also give us a perspective on how mangroves may respond to several different sea-level change scenarios. However, these tend to mask the details of response; sedimentation rate determined over the long-term average of sedimentation, reduce the variability which is indicated by the contemporary morphology of the mangrove substrate, and the logic of identifying mangrove sediment sources.

If, for the sake of argument, average sedimentation rates beneath Sonneratia were $5 \mathrm{~mm} \mathrm{yr}^{-1}$ because of the active tidal input of sediment, beneath Rhizophora $6 \mathrm{~mm} \mathrm{yr}^{-1}$ in view of the 

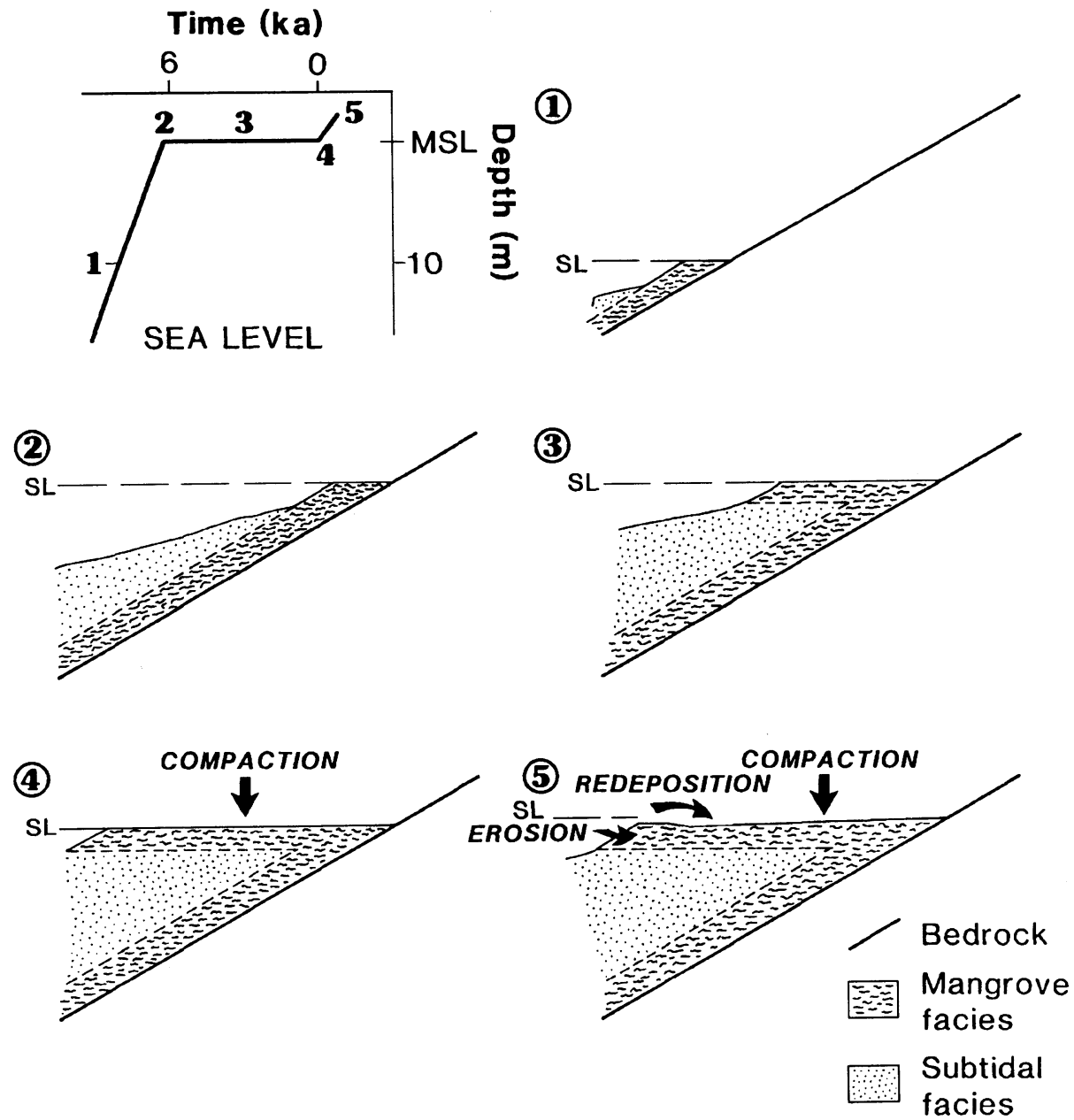

Fig. 7 Schematic representation of history of sea-level change and geomorphology of a coastal plain in the Northern Territory of Australia. (from Woodroffe, 1995) 1. Around 8000 years BP, sea level is rising rapidly and there is a transgressive shoreline. 2. Around 6000 years BP when sea level stabilised at a level close to present and the shoreline was at the rear of the present coastal plain. 3. Around 3000 years BP, sea level has been stable, and the coast has prograded. 4. Modern, the shoreline has built seaward and a low-lying coastal plain exists. 5. Hypothetical situation if the sea rises in future; shoreline erosion is accompanied by saline incursion into the coastal plain. Note that this situation is not directly analogous to sea-level rise on a steep coast as occurred at time 1.

incorporation of organic production into the substrate as below ground biomass, rates beneath tidal flat Ceriops $2 \mathrm{~mm} \mathrm{yr}^{-1}$, and rates beneath hinterland margin $3 \mathrm{~mm} \mathrm{yr}^{-1}$ because of the enhanced colluvial input, then such spatially disparate rates might give rise to a profile that consisted of a steeper gradient on creek banks beneath the tidal creek mangroves, a relatively flat profile through the low sedimentation rates areas of the basin mangrove, but a wedge of colluvial sediment around the hinterland margin. Stratigraphic reconstructions, based upon radiocarbon dating of organic matter in sediments at depth beneath the profile would tend to give a view of sedimentation rate that was 
relatively low. This would be still more the case if the material that was dated had been intruded into the sediment as root material, rather than being deposited contemporaneously with the sediment surface.

Furthermore, it depends upon whether the sea is rising or is stable which is interrelated to the extent to which there is a steady-state hydrodynamic regime (Wolanski \& Chappell, 1996), and the degree to which there is a supply of allochthonous sediment.

The Holocene stratigraphic record is especially useful because it indicates that mangrove forests have been extensive under conditions during which the sea level has risen at rates substantially greater than those presently being experienced in most parts of the tropics, or predicted in the most widely accepted greenhouse scenarios. Further research on these transgressive deposits is likely to indicate the nature of the response to particular long-term rates of sea-level rise. However, in addition to recognising that radiocarbon dating is likely to give depth- and time-averaged estimates of sea-level rise, there are also some important other differences to consider between the rapid rise of sea level in the early or mid-Holocene and what may eventuate if predicted sea-level rise occurs.

The situation is examined in Fig. 7 for a typical coastal plain along the northern Australian coastline. The stratigraphy and morphology of the plain is shown at a number of points in time. About 8000 years ago, the sea was rising rapidly. Mangroves were found on the coast, but were presumably migrating inland and replacing terrestrial vegetation as the sea inundated previously dry land. Around 6000 years ago the sea stabilised and mangrove forests existed at what is now the landward margin of the coastal plain. Around 3000 years ago the plain had prograded through the accumulation of marine sediments in the nearshore and the further accumulation of intertidal (and supratidal) sediments across the plain. Subsequently the plain continued to build seaward to its present position.

If the sea were to rise in the future, then water levels would extend inland beyond the present landward margin of the mangroves. However, this situation now differs from that 8000 years ago, because instead of a simple mangrove fringe flanking terrestrial vegetation, there is now a broad progradational plain separating the mangroves from the terrestrial vegetation. A number of responses could be anticipated on the coastal plain. First, it is not unlikely that the sediments of the plain, consisting of unconsolidated sediments, might compact over the millennia during which it has built seaward. In that case, the plain surface might now be below the level at which it had formed, and indeed, as is the case along such plains in northern Australia, might be below sea level at the present coast, but inundation would be prevented by the distance and subtle supratidal deposits landward of the present mangrove firnge.

As the sea rises, it will flood across the low-gradient plains. Generally such flooding progresses by a gradual wetting front at high spring tides, with the water penetrating into the dried plains surface rather than spreading right across it. The wetting front can migrate further across the plain during each successive tide, but generally as tidal levels decrease once the spring tide has passed, only a short distance of inundation occurs until the next spring tide two weeks later.

Alternatively, tidal waters may find low-lying points and exploit these to cut back into the plains. Rapid incision may occur where easily erodible sediments occur, and expansion of tidal creeks into the plains represents a means by which salinisation can progress. An example of such tidal creek expansion, and salinisation of coastal plains has been described from the Mary River in the Northern Territory. In this case there is no evidence that this incursion has occurred as a result of sea-level rise. 
Indeed there appears to have been negligible sea-level rise and some other cause needs to be invoked.

\section{Conclusion}

While anticipated sea-level rise caused by the global environmental change will undoubtedly have an impact on mangrove shorelines, there is still considerable uncertainty as to all of the implications. Though changes may be observed in mangroves, it remains difficult to decide whether these are natural changes, human-induced changes, or a response to global environmental change. Human impact has been enormous, leading to extensive degradation of mangroves, beyond the scope of this review; separating these different impacts remains a challenge. Similarly, the effects of other facets of global environmental change on mangroves needs to be considered; increased storminess, or enhanced rainfall may have an impact on mangroves which in some cases may enhance, or ameliorate, the effect of sea-level rise.

Further understanding of sedimentation rates within mangrove forests is clearly required. In particular there is a need to address the spatial variability of potential rates, and the role of plant production, in terms of below ground biomass, and its contribution to substrate accretion.

Zonation of mangroves should not be viewed as an indication of a successional trend by which mangroves species may undergo successive replacement culminating in a terrestrial climax vegetation. However, it is clear that over the long-term replacement of mangrove species does occur, with landwards migration likely under conditions in which sea-level rise is high in relation to sedimentation rate. Further understanding of population structure and the changes in the ecotones between mangrove communities will be required to fully understand these dynamics.

\section{REFERENCES}

Alleng, G. P., 1998. Historical development of the Port Royal Mangrove Wetland, Jamaica. Journal of Coastal Research 14: 951-959.

Bird, E. C. F., 1971. Mangroves as land-builders. Victorian Naturalist 88: 189-197.

1986. Mangroves and intertidal morphology in Westernport Bay, Victoria, Australia. Marine Geology 69: 251-271.

Carlton, J. M., 1974. Land-building and stabilization by mangroves. Environmental Conservation 1: 285-294.

Chapman, V. J., 1944. 1939 Cambridge University Expedition of Jamaica. Part 1. A study of the botanical processes concerned in the development of the Jamaican shoreline. Journal of the Linnean Society (London) Botany 52: 407-447.

, 1976. Mangrove Vegetation, 447 pp. J. Cramer, Germany.

\& Ronaldson, J. W., 1958. The mangrove and salt marsh flats of the Auckland Isthmus. NZ Department of Scientific and Industrial Research Bulletin 125: 1-79.

Chappell, J. \& Grindrod, J., 1984. Chenier Plain Formation in Northern Australia. In:. Thom, B.G (ed.), Coastal Geomorphology, pp. 197-231. Academic Press, Sydney.

_\& Shackleton, N. J., 1986. Oxygen isotopes and sea level. Nature 324: 137-140. 
Clark, J. A., Farrell, W. E. \& Peltier, W.R., 1978. Global change in post glacial sea level: a numerical calculation. Quaternary Research 9: 265-287.

Clark, R. L. \& Guppy, J. C., 1988. A transition from mangrove forest to freshwater wetland in the monsoon tropics of Australia. Journal of Biogeography 15: 665-684.

Crowley, G. M., 1996. Late Quaternary mangrove distribution in Northern Australia. Australian Systematic Botany 9: 219-225.

Davis, J. H., 1938. Mangroves: makers of land. Nature Magazine (November): 551-553. 1940. The ecology and geologic role of mangroves in Florida. Papers from Tortugas Laboratory 32: 307-412.

Egler, F. E., 1952. Southeast saline everglades vegetation, Florida: and its management. Vegetatio 3: 213-265.

Ellison, J. C., 1993. Mangrove retreat with rising sea-level, Bermuda. Estuarine Coastal and Shelf Science 37: 75-87.

— \& Stoddart, D. R., 1991. Mangrove ecosystem collapse during predicted sea-level rise: Holocene analogues and implications. Journal of Coastal Research 7: 151-165.

Ewel, K. C., Twilley, R. R. \& Ong, J. E., 1998. Different kinds of mangrove forests provide different goods and services. Global Ecology and Biogeography Letters 7: 83-94.

French, J. R., 1993. Numerical simulation of vertical marsh growth and adjustment to accelerated sealevel rise, North Norfolk, UK. Earth Surface Processes and Landforms 18: 63-81.

Gagan, M. K., Johnson, D. P. \& Crowley, G. M., 1994. Sea level control of stacked late Quaternary coastal sequences, central Great Barrier Reef. Sedimentology 41: 329-351.

Geyh, M. A., Kudrass, H.-R. \& Streif, H., 1979. Sea-level changes during the late Pleistocene and Holocene in the Strait of Malacca. Nature 278: 441-443.

Grindrod, J., 1985. The palynology of mangroves on a prograded shore, Princess Charlotte Bay, North Queensland, Australia. Journal of Biogeography 12: 323-348.

-1988. The palynology of Holocene mangrove and saltmarsh sediments, particularly in northern Australia. Review of Palaeobotany and Palynology 55: 229-245.

— Rhodes, E. G., 1984. Holocene sea level history of a tropical estuary: Missionary Bay, North Queensland. In: Thom, B. G. (ed.), Coastal Geomorphology in Australia, 151-178. Academic Press, Sydney.

Hutchings, P. \& Saenger, P., 1987. Ecology of Mangroves, 388 pp. University of Queensland Press, Queensland.

Knighton, A. D., Mills, K. \& Woodroffe, C. D., 1991. Tidal creek extension and saltwater intrusion in northern Australia. Geology 19: 831-834.

- Woodroffe, C. D. \& Mills, K., 1992. The evolution of tidal creek networks, Mary River, Northern Australia. Earth Surface Processes and Landforms 17: 167-190.

Lighty, R. G., Macintyre, I. G. \& Stuckenrath, R., 1982. Acropora Palmata reef framework: a reliable indicator of sea level in the western Atlantic for the past 10,000 years. Coral Reefs 1: 125-130.

Lugo, A. E. \& Snedaker, S. C., 1974. The ecology of mangroves. Annual Review of Ecology and Systematics 5: 39-64.

Lynch, J. C., Meriwether, J. R., McKee, B. A., Vera-Herrera, F. \& Twilley, R.R., 1989. Recent accretion in mangrove ecosystems based on ${ }^{137} \mathrm{Cs}$ and $210 \mathrm{~Pb}$. Estuaries 12: 284-299. 
Macnae, W., 1968. A general account of the fauna and flora of mangrove swamps and forests in the Indo-West-Pacific region. Advances in Marine Biology 6: 73-270.

Parkinson, R. W., 1989. Decelerating Holocene sea-level rise and its influence on southwest Florida coastal evolution: a transgressive/regressive stratigraphy. Journal of Sedimentary Petrology 59: 960-972.

Scholl, D.W., 1964. Recent sedimentary record in mangrove swamps and rise in sea level over the southwestern coast of Florida: Part 1. Marine Geology 1: 344-366.

- Craighead, F. C. \& Stuiver, M., 1969. Florida submergence curve revised: its relation to coastal sedimentation rates. Science 163: 562-564.

— \& Stuiver, M., 1967. Recent submergence of southern Florida: a comparison with adjacent coasts and other eustatic data. Geological Society of America Bulletin 78: 437-454.

Semeniuk, V., 1980. Mangrove zonation along an eroding coastline in King Sound, northwestern Australia. Journal of Ecology 68: 789-812.

1983. Mangrove distribution in northwestern Australia in relationship to regional and local freshwater seepage. Vegetatio 53: 11-31.

1985a. Development of mangrove habitats along ria shorelines in north and northwestern tropical Australia. Vegetatio 60: 3-23.

1985b. Mangrove environments of Port Darwin, Northern Territory: the physical framework and habitats. Journal of the Royal Society of Western Australia 67: 81-97.

Smith, W., 1968. Sedimentary Environments and Environmental Change in the Peat-Forming Area of South Florida. PhD Thesis, Pennyslvania State University.

Snedaker, S. C., 1995. Mangroves and climate change in the Florida and Caribbean region: scenarios and hypotheses. Hydrobiologia 295: 43-49.

, Meeder, J. F., Ross, M. S. \& Ford, R. G., 1994. Discussion of Ellison, Joanna C. and Stoddart, David R., 1991. Mangrove ecosystem collapse during predicted sea-level rise: Holocene analogues and implications. Journal of Coastal Research 7 (1), 151-165. L.c. 10: 497-498.

Spackman, W., Dolsen, C. P. \& Riegel, W., 1966. Phytogenic organic sediments and sedimentary environments in the everglades - mangrove complex. Paleontographica Abt. B, 117: 135-152.

Spenceley, A. P., 1977. The role of pneumatophores in sedimentary processes. Marine Geology 24: M31-M37.

- 1982. Sedimentation patterns in a mangal on Magnetic Island near Townsville, north Queensland, Australia. Singapore Journal of Tropical Geography 3: 100-107.

1987. Mangroves and intertidal morphology in Westernport Bay, Victoria, Australia: comment. Marine Geology 77: 327-331.

Thom, B. G., 1967. Mangrove ecology and deltaic geomorphology: Tabasco, Mexico. Journal of Ecology 55: 301-343.

1982. Mangrove ecology: a geomorphological perspective. In: Clough, B.F. (ed.), Mangrove Ecosystems in Australia, Structure, Function and Management, pp. 3-17. ANU Press, Canberra.

Tjia, H. D., 1996. Sea-level changes in the tectonically stable Malay-Thai peninsula. Quaternary International 31: 95-101.

Van Andel, T. H., 1967. The Orinoco Delta. Journal of Sedimentary Petrology 37: 297-310.

Wolanski, E. \& Chappell, J., 1996. The response of tropical Australian estuaries to a sea level rise. 
Journal of Marine Systems 7: 267-279.

Woodroffe, C. D., 1981. Mangrove swamp stratigraphy and Holocene transgression, Grand Cayman Island, West Indies. Marine Geology 41: 271-294.

- 1990. The impact of sea-level rise on mangrove shorelines. Progress in Physical Geography 14: 483-520.

1992. Mangrove sediments and geomorphology. In: Alongi, D. \& Robertson, A. (ed.), Tropical Mangrove Ecosystems, pp. 7-41. American Geophysical Union, Coastal and Estuarine Studies.

1995. Response of tide-dominated mangrove shorelines in northern Australia to anticipated sea-level rise. Earth Surface Processes and Landforms 20: 65-85.

—, Bardsley, K. N., Ward, P. J. \& Hanley, J.R., 1988. Production of mangrove litter in a macrotidal embayment, Darwin Harbour, N.T., Australia. Estuarine, Coastal and Shelf Science 26: 581-598.

— Chappell, J., Thom, B.G. \& Wallensky, E., 1986. Geomorphological dynamics and evolution of the South Alligator River and plains, N. T. North Australia Research Unit Monograph. ANU Press.

- Thom, B. G. \& Chappell, J., 1985. Development of widespread mangrove swamps in midHolocene times in northern Australia. Nature 317: 711-713.

Alligator River region, North Australia, during the Holocene. Search 18: 198-200.

Accepted March 12, 1999

\section{Colin D. WOODRPFFE}

\section{海水準変動に対するマングローブ海岸の応答}

海水準変動に対するマングローブ海岸の応答は, そこへの堆積物供給量によって決定される。同時に, マ ングローブ域自体の有機物生産も指摘され, これらの物質が隣接するエスチュアリにもたらされる。全体 としてみれば堆積の場と考えられる。

マングローブ林は, しばしば海岸に並行した帯状構造を形成するが, これは必ずしも逻移系列を意味す るもではなく, また海岸線の前進傾向を反映しているものとも限らない。ではあるけれど, フロリダ半島 南西部, エバクラデスの淡水林に接するマングローブ林では, 過去数千年の海面上昇に伴う, マングロー ブ植生のランドビルダーとしての役割が首位的に分析されている。いわゆるマングローブ堆積物は, 第四 紀後期の海面変動パターンや, 過去の海面変化に対応した海岸線変動を解析するのに有効な指示堆積物で ある。概して海面上昇の指示物として有効で, とりわけ無機物の供給が迅速な沿岸におけるマングローブ 起源の有機物の蓄積は, 環境変化をあとづける有効な指示物である。

海岸線の動きとマングローブ林の立地変動との関保は, その森が置かれている嘸境設定によって異なる が, 立地の枠組み自体は, マングローブ種の生態的特性によって作られる。マングローブ林での堆積作用 は, 海面変動に対応した海岸線の動きを大きく変化させるほどの役割は果たしていないと考えられ，長い タイムスケールでみた堆積速度が, マングローブ海岸の立地変動に関与するのではないか。マングローブ 海岸の変化は様々な形で引き起こされ, 自然条件下, 人為が加えられた状態, 地球環境変動に対する応答, さらには地域差などがあり，これらを踏まえてマングローブ海岸の変化を理解することが必要である。 